\title{
Atmospheric Iron and Aluminium Deposition and Sea-Surface Dissolved Iron and Aluminium Concentrations in the South China Sea off Malaysia Borneo (Sarawak Waters)
}

\author{
FARAH AKMAL IDRUS ${ }^{1, *}$, KHAIRUL NIZAM MOHAMED ${ }^{2}$, NUR SYAZWANI ABDUL \\ RAHIM $^{1} \&$ MELISSA DENNIS CHONG ${ }^{1}$
}

\author{
${ }^{1}$ Faculty of Resource Science and Technology, Universiti Malaysia Sarawak, 94300 Kota Samarahan, Sarawak, \\ Malaysia; ${ }^{2}$ Department of Environment, Faculty of Forestry and Environment, Universiti Putra Malaysia, 43400 \\ Serdang, Selangor, Malaysia \\ *Corresponding author: aifarah@unimas.my \\ Received: 10 November 2021 \\ Accepted: 12 December 2021 \\ Published: 31 December 2021
}

\begin{abstract}
South China Sea (SCS) is an oligotrophic sea which usually receives low nutrients supply. However, massive atmospheric dust input was occurred during the haze event in Southeast Asia for almost every year. The input of dissolved iron (DFe) and dissolved aluminium (DAl) from dust and nearby land into SCS off Sarawak Borneo region during the worst haze event in 2015 of the Southeast Asia were investigated. The estimation dust deposition during this study was $0.162 \mathrm{mg} / \mathrm{m}^{2} / \mathrm{yr}$. The atmospheric fluxes of total $\mathrm{Fe}$ and total $\mathrm{Al}$ at the offshore Sarawak waters were $0.611 \mu \mathrm{mol} / \mathrm{m}^{2} / \mathrm{yr}$ and $2.03 \mu \mathrm{mol} / \mathrm{m}^{2} / \mathrm{yr}$, respectively, where the readily available dissolved $\mathrm{Fe}$ and $\mathrm{Al}$ from the dust were $0.11 \mu \mathrm{mol} / \mathrm{m} 2 / \mathrm{yr}(\mathrm{DFe})$ and $0.31 \mu \mathrm{mol} / \mathrm{m}^{2} / \mathrm{yr}$ (DAl). Fe has higher solubility (17.78\%) than $\mathrm{Al}$ $(15.21 \%)$. The lateral fluxes (e.g. from the nearby land) were $37.08 \mathrm{nmol} / \mathrm{m}^{2} / \mathrm{yr}(\mathrm{DFe})$ and $125 \mathrm{nmol} / \mathrm{m}^{2} / \mathrm{yr}(\mathrm{DAl})$, with strong Fe organic ligand class $\mathrm{L}_{1}(\log \mathrm{K}: 22.43$ - 24.33). High concentrations of DFe and DAl at the surface water of the offshore region, coincided with high concentration of macronutrients due to the prevailing southwesterly winds originated from the west Kalimantan. Low residence times, $\sim 0.92$ (DFe) and $\sim 1.31$ (DAl) years, corresponded well with DAlexcess in surface seawater due to biological utilization of DFe. Future works emphasize on natural organic $\mathrm{Fe}$ (III) ligands and phytoplankton study are needed for better understanding on biogeochemistry of Fe and $\mathrm{Al}$ at SCS off Malaysia Borneo.
\end{abstract}

Keywords: Atmospheric dust input, haze event 2015, Sarawak EEZ waters, South China Sea, trace metals

Copyright: This is an open access article distributed under the terms of the CC-BY-NC-SA (Creative Commons Attribution-NonCommercial-ShareAlike 4.0 International License) which permits unrestricted use, distribution, and reproduction in any medium, for non-commercial purposes, provided the original work of the author(s) is properly cited.

\section{INTRODUCTION}

Vegetation and peatland wildfires occurred every year across the Equatorial Asia, particularly at the Southeast Asia, during the dry season between September and October. The 2015 wildfire that started in Indonesia Borneo and then spread to Sarawak (Malaysia Borneo) began in July, resulted in thick smokes that blanketed Southeast Asia countries, such as, Malaysia, Brunei, Indonesia, Thailand and Singapore. It was likely the worst haze event since 1997 (Koplitz et al., 2016). The combustion activities were worsening by drought conditions during the El Nińo and the Indian Ocean Dipole, where the fire emissions can be rose up to 30 times greater than during La Nińa (Crippa et al., 2016). Moreover, the prevailing winds transported the wildfire smokes for hundreds to thousands miles away from the originating fires on the land to the sea, thus, the spatial and temporal effect of atmospheric inputs on surface seawater biogeochemistry may be seen even in remote oceanic areas.

South China Sea (SCS) is the largest marginal sea with oligotrophic condition (Wen et al., 2006) which receives low nutrients supply (Guo et al., 2012), where the nutrients may come from different sources such as coastal and atmospheric inputs (Chen et al., 2021). Studies showed that there were significant inputs of micronutrients (i.e. $\mathrm{Fe}$ and $\mathrm{Al}$ ) from atmospheric dust deposition in SCS due to the strategic location of SCS (Lin et al., 2007; Wong et al., 
2002; Wong et al., 2007; Du et al., 2021). However, Fe data from Sarawak waters off the SCS were absent since approximately 20 years ago, with the available data was from 1996 and 1997 (Boonyapiwat, 2000), while Al data was absent since then.

$\mathrm{Fe}$ is very important element for marine organisms, which $\mathrm{Fe}$ acts as a key element for biological processes to take place including photosynthesis, uptake of nitrates, fixation of $\mathrm{N}_{2}$, and detoxification of reactive oxygen species in seawater (Berman-Frank et al., 2004; Rijkenberg et al., 2008; Shi et al., 2020). Picophytoplankton is the most tolerate taxa to low nutrient condition in oligotrophic seawater. However, even this taxa is also affected when the supply of $\mathrm{Fe}$ and other nutrients are very low. Fe in seawater is originated from various sources such as atmospheric (e.g. aerosol) dust, riverine and sediment inputs. Meanwhile, $\mathrm{Al}$ is known as an ideal tracer to indicate the dust input into the surface seawater because it is a major and invariant component of continental materials and also it has low solubility with a range of 1.5 to $10 \%$ in rainwater and seawater, respectively (Gehlen et al., 2003). In addition, strong evidence showed that $\mathrm{Al}$ was driven primarily by dust deposition as surface $\mathrm{Al}$ concentration was directly proportional to dust deposition (Measures \& Vink, 2000). Other significant inputs of $\mathrm{Al}$ into the seawater is riverine run-off while sediment input is minimum since scavenged $\mathrm{Al}$ from surface water is biologically recycled (Kraemer, 2004).

Therefore, the objective of this study was to investigate the input of $\mathrm{Fe}$ and $\mathrm{Al}$ from the atmospheric dust deposition and from the nearby land into the Sarawak waters off the SCS during the worst haze event in 2015. The research approach is to use the trace metal concentrations to estimate the solubility, residence time, atmospheric and lateral metal fluxes at the study region.

\section{MATERIALS AND METHODS}

\section{Study Sites and Samples Collection}

Samples collection were done in Sarawak EEZ waters on board of $M V S E A F D E C 2$ between $17^{\text {th }}$ of August and $5^{\text {th }}$ of October 2015. A total of 12 stations were selected for surface seawater sampling, where stations were divided into three areas (i.e. Area I (nearshore), Area II (midshore) and Area III (offshore)) (Figure 1). For aerosol samples, four samples were collected around Areas I and II while five samples were collected around Area III. For the aerosol samples, $\mathrm{PM}_{10}$ were collected from the bridge of the ship within 6 hours (Zhang et al., 2007) when the ship moved (to avoid contamination from the exhaust smoke) by using a low volume pump air sampler (MiniVol portable air sampler) equipped with $0.45 \mu \mathrm{m}$ of membrane filter (Sartorius Polyamid, 37070) and calibrated to a flow rate of $10 \mathrm{~L} / \mathrm{min}$ using bubble flow meter. The filter papers were placed in clean double zipper plastic bags and then in acidwashed container labelled with sampling details. Filter papers for $\mathrm{Fe}$ and $\mathrm{Al}$ analyses were suspended into $25 \mathrm{~mL}$ of ammonium acetate buffer solution ( $\mathrm{pH} 4.7$ ) for $60-120$ minutes to release the aerosol samples. Then, the supernatants were filtered using $0.2 \mu \mathrm{m}$ cellulose acetate filter papers and acidified with $0.08 \mathrm{M} \mathrm{HNO}_{3}$ in $50 \mathrm{~mL}$ vials for dissolved $\mathrm{Fe}$ $(\mathrm{DFe})$ and dissolved $\mathrm{Al}$ (DAl) analyses, meanwhile the unfiltered supernatants were used to analyse total concentrations of $\mathrm{Fe}(\mathrm{TFe})$ and $\mathrm{Al}$ (TAl). $\mathrm{Fe}$ and $\mathrm{Al}$ concentrations were determined by using inductively coupled plasma optical emission spectrometry (ICP-OES) (Perkin Elmer, Optima 8000). Filter papers that were not exposed to the dust were used as blanks and treated the same way as samples (Sarthou $e t$ al., 2003).

Surface seawater samples were collected using Van Dorn water sampler $(5.0 \mathrm{~L})$ at $\sim 3 \mathrm{~m}$ depth. All $500 \mathrm{~mL}$ samples were filtered $(0.45$ $\mu \mathrm{m})$ and stored in acid-washed bottles, then acidified to $\mathrm{pH} \sim 2$ using $12 \mathrm{M} \mathrm{HCl}$ (R\&M chemical analytical reagents) and were kept in double re-sealable zipper plastic bags. For Fe speciation analysis, $250 \mathrm{~mL}$ of filtered seawaters were collected into high density polyethylene bottles (Nalgene) and immediately frozen at -20 ${ }^{\circ} \mathrm{C}$ (not acidified) for subsequent land-based analysis.

\section{Trace Metal Analysis}

Analysis of DFe conducted following the method provided by Idrus (2016), while for DAl, analysis conducted was followed the method by Brown and Bruland (2008). Off-line preconcentration technique was applied using commercially available chelating resin with 
IDA-type functional groups Toyopearl AF Chelate 650M resin (Part No. 19800, Tosoh Bioscience). Prior to pre-concentration, samples $\mathrm{pH}$ was adjusted to $4.5(\mathrm{Fe})$ and $5.75(\mathrm{Al})$ by adding $0.4 \mathrm{M}$ ammonium acetate buffer and analysed using ICP-OES (Perkin Elmer, Optima 8000) (Ali and Shakrani, 2014). Certified Reference Material (CASS-5) was used in the Fe calibration procedure. The percentage recovery obtained for $\mathrm{Fe}$ was $95 \%$. For Al, percentage recovery was determined by using the internal standards. The internal standard solutions were prepared using the treated assigned water samples in the same way of samples. The percentage recovery for $\mathrm{Al}$ obtained was $90 \%$.

The Fe speciation analysis was undertaken using competitive ligand exchange-adsorptive cathodic stripping voltammetry (CLE-ACSV) with TAC (thiazolylazo-p-cresol; SigmaAldrich) as competing ligand (Mohamed et al., 2011).

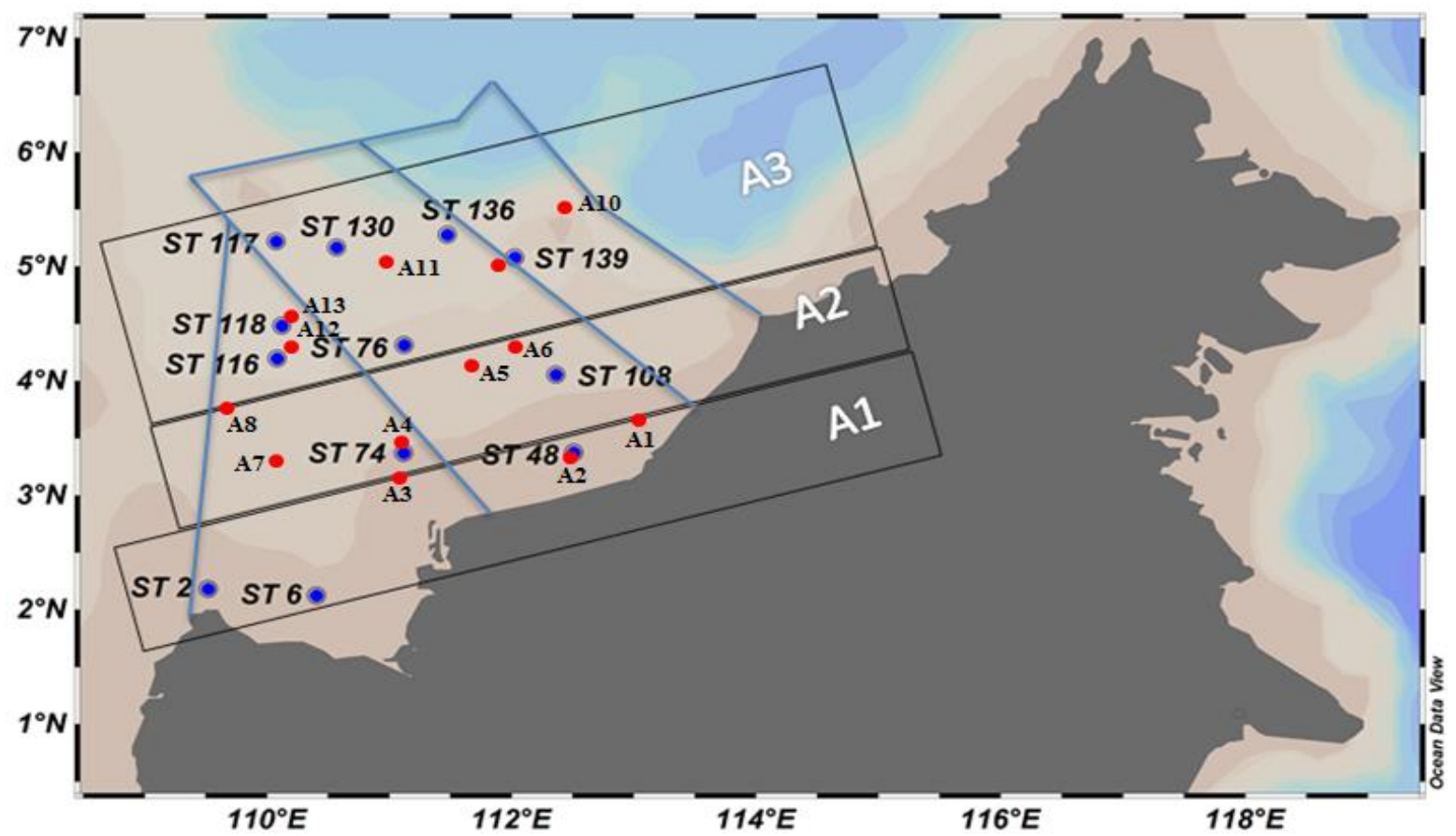

Figure 1. Map of sampling locations located at Sarawak water during MV SEAFDEC 2 research from 17 August to 5 October 2015. A1: Area I; A2: Area II; A3: Area III. Blue dots: Surface waters sampling stations; Red dots: Aerosol sampling stations; Blue line represents the area of Sarawak waters

Estimation of solubility, residence time, atmospheric and lateral metal fluxes

Solubility of $\mathrm{Fe}$ in aerosol samples was measured as according to Chance et al. (2015). Assuming that the study areas were in steady state conditions, the atmospheric dust deposition (D) in the study area can be estimated by using DAl data obtained from this study following the method as explained in de Jong et al. (2007). Then, the atmospheric dust deposition flux was used for calculating of total trace metal atmospheric flux $\left(\mathrm{F}_{\mathrm{atm}}, \mathrm{T}_{\mathrm{TM}}\right)$. Dissolved metals $\left(\mathrm{F}_{\mathrm{atm}}, \mathrm{D}_{\mathrm{TM}}\right)$ fluxes were calculated using obtained value of total flux of trace metals. Residence time is the average length of time that trace metals or any elements retained in the water column before removed from the water column (in the steady state condition). Residence times of trace metals were calculated by using the average of DFe and DAl at the surface water multiplying with the mixed layer depth and then divided by the $\mathrm{F}_{\mathrm{atm}}, \mathrm{D}_{\mathrm{TM}}$.

The horizontal fluxes of trace metal ( $\left.\mathrm{F}_{\mathrm{DTM}}\right)$ were calculated by using the distance from the station located very close to the shore and the scale (the distance takes for the inshore concentration to drop by $1 / \mathrm{e}$ was estimated from the $\ln ([\mathrm{Fe}])$ or $\ln ([\mathrm{Al}]))$ (Aguilar-Islas et al., 2013) (Fe, $285.0 \mathrm{~km}$; Al, $158.0 \mathrm{~km})$. The exponential fit of $[\mathrm{DFe}]=4.048 \mathrm{e}^{\mathrm{x} / 285.0}$ while $[\mathrm{DAl}]=2.0728 \mathrm{e}^{\mathrm{x} / 158}$. Then, the parameterization was used to estimate lateral diffusion coefficient $\left(\mathrm{K}_{h}, \mathrm{~m}^{2} / \mathrm{s}\right)$. 


\section{Other Calculation}

Pearson's correlation coefficient (r) and scatterplots were used to quantify linear relationships between variables. Correlation coefficients were compared to the Pearson critical value for significance level $p=0.05$ to test whether observed correlations were significant.

\section{RESULTS AND DISCUSSION}

The back trajectory analysis was conducted to determine the origin of air masses and established the source-receptor relationships. The information on back trajectories were comprehensively described in National Oceanic and Atmospheric Administration (NOAA) web portal (http:// ready. arl. noaa. gov/ HYSPLIT. php). In this study, back trajectories were plotted by using free online available software of NOAA HYSPLIT model, by setting one point at Area III (the farthest station) to determine the origin of wind that move towards or pass through the study area (Figure 2). Backward trajectory confirmed that prevailing southwesterly winds were originated from west Kalimantan and passed throughout our study locations. Wind that originated from West Kalimantan would possibly bring together all the particles that produce from biomass burning activities at that area.

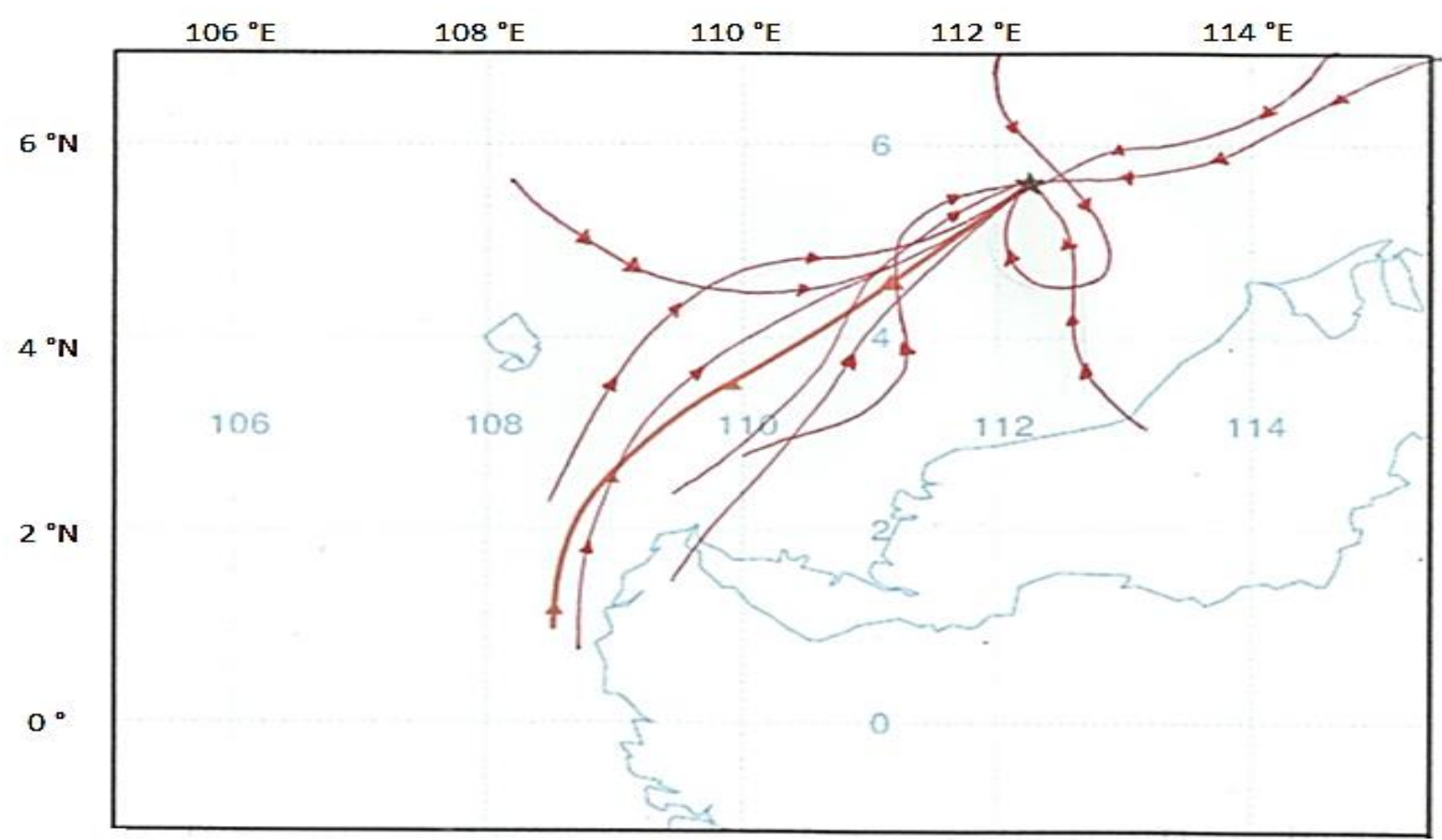

Figure 2. Backward trajectories of prevailing winds during sampling period. Black star is a point that set at Area III to determine the origin of wind that move towards or pass through the study area. Red arrow represents the direction of wind from origin towards the sampling area

Many efforts had been done to suppress fires, but they were more challenging during El Niño conditions and on peatlands (Cattau et al., 2016). Smoke from biomass burning activities contain high concentration of biologically important macro- and micro-nutrients (i.e. trace metals) (Hapsari et al., 2021; Ponette-Gonzalez et al., 2016). Emitted gasses and particles would be delivered to downwind, in this case from West Kalimantan towards Sarawak water and deposited into the water column via wet or dry deposition. In addition, one volcanic eruption was reported on the $30^{\text {th }}$ of August 2015 at
Lakon-Empung, Sulawesi Indonesia. The ash plumes from this eruption rose to an altitude up to $3 \mathrm{~km}$ and transported to nearby area including Malaysian waters (Global Volcanism Programme, 2013).

$\mathrm{DFe}$ and DAl distributions in surface water are presented in Table 1 . The DFe concentrations were ranged from 10 to $278 \mathrm{nM}$ $(n=12)$ while DAl concentration were ranged between 7.82 and $24.98 \mathrm{nM}(n=12)$. Overall, offshore stations were detected with high concentration of DFe and DAl, coincided with 
high concentrations of Nitrogen (N) and Phosphorus (P) (i.e. Station 116 and Station 76) (Idrus et al., 2017). Results showed that distribution patterns of DFe and DAl were: Area III > Area II > Area I, indicated that concentration of DFe and DAl were increasing relative to distance from shoreline and possibly due to input from aerosol deposition. Lin et al. (2009) and de Jong et al. (2007) suggested the area that further away from coastline has a greater impact of nutrient input from atmospheric aerosols because the chances of nutrient input from another sources are lower. Atmospheric aerosols have been hypothesized as an important nutrients source to stimulate biogeochemical activities in the SCS (Ho et al., 2010; Jickells et al., 2005; Lin et al., 2009;
Wong et al., 2002; Wong et al., 2007; Wen et al., 2006; Du et al., 2021). The high DFe and DAl concentrations were coinciding with the maximum concentration of Chl-a (Idrus et al., 2017) in Area I. However, the N and P at these stations were low (Idrus et al., 2017). DFe concentration in seawater obtained in this study fall between concentration range reported by Utoomprurkporn and Snidvongs (1999) during Matahari Expedition in Sabah, Sarawak and Brunei waters. DAl concentrations obtained in this study were lower than the values in the Yellow Sea (Li et al., 2013) and in the SCS around the Pulau Perhentian, Terengganu (Mohamaed et al., 2019), as their study areas were affected by eddies that generated input from bottom sediment.

Table 1. The coordinates, dissolved Fe (DFe) and dissolved Al (DAl) concentrations for each station from 17 August 2015 to 5 October 2015 at Sarawak waters (surface water)

\begin{tabular}{cccccc}
\hline Area & Station & Longitude $\left({ }^{\circ} \mathrm{E}\right)$ & Latitude $\left({ }^{\circ} \mathrm{N}\right)$ & $\mathrm{DFe}(\mathrm{nM})$ & $\mathrm{DAl}(\mathrm{nM})$ \\
\hline I & 48 & 112.511 & 3.374 & $79.00 \pm 0.34$ & $11.08 \pm 0.01$ \\
& 6 & 110.122 & 4.480 & $47.00 \pm 0.02$ & $7.82 \pm 0.03$ \\
& 2 & 110.087 & 4.194 & $59.00 \pm 0.20$ & $7.82 \pm 0.06$ \\
II & 108 & 112.364 & 4.052 & $10.00 \pm 0.34$ & $13.86 \pm 0.01$ \\
& 74 & 111.227 & 4.575 & $62.00 \pm 0.14$ & $7.82 \pm 0.01$ \\
III & 139 & 112.027 & 5.075 & $81.00 \pm 0.14$ & $18.94 \pm 0.03$ \\
& 136 & 111.475 & 5.275 & $88.00 \pm 0.08$ & $18.94 \pm 0.03$ \\
& 76 & 111.122 & 3.371 & $278.00 \pm 0.32$ & $24.98 \pm 0.01$ \\
& 130 & 111.166 & 4.015 & $189.00 \pm 0.21$ & $16.79 \pm 0.01$ \\
& 117 & 111.126 & 4.311 & $105.00 \pm 0.56$ & $16.79 \pm 0.11$ \\
& 118 & 110.573 & 5.168 & $68.00 \pm 0.36$ & $15.46 \pm 0.01$ \\
& 116 & 110.078 & 5.219 & $224.00 \pm 0.97$ & $18.94 \pm 0.03$ \\
\hline
\end{tabular}

Total $\mathrm{Fe}$ (TFe), total $\mathrm{Al}$ (TAl), DFe, DAl distribution in aerosol samples are shown in Table 2. High concentrations of TFe $(6.65 \pm 0.99$ $\left.\mathrm{mg} / \mathrm{m}^{3}\right), \mathrm{DFe}\left(0.96 \pm 0.06 \mathrm{mg} / \mathrm{m}^{3}\right), \mathrm{TAl}(1.41 \pm$ $\left.0.02 \mathrm{mg} / \mathrm{m}^{3}\right)$ and DAl $\left(0.19 \pm 0.01 \mathrm{mg} / \mathrm{m}^{3}\right)$ in aerosol samples were recorded at Station 9 (Area III). Similar pattern of $\mathrm{Fe}$ and $\mathrm{Al}$ distributions were observed between surface water samples and aerosol samples. Fe and Al concentrations in aerosol were higher at Area III, suggested that both elements were coming from similar origin during this study which could have related to the starting of Northeast monsoon event as suggested by Huang \& Lin (2015) and Lin et al. (2007). This high deposition of dust brings together other nutrients into surface water which could enrich the productivity. Based on aerosol optical depth (AOD) observation around SCS, high AOD was found at offshore areas of China, Indochina, Sumatra and Borneo (Huang and Lin,
2015). Thus, dust deposition was dominated at offshore areas (Areas III and II) compared to near-shore area (Area I). Previous studies indicated that smokes from biomass burning in Borneo and Sumatra were the main sources of trace metals and nutrients content in aerosol at the southern SCS from August to October correspond to high aerosol optical thickness (AOT) with fine dust particles (Holloway et al., 2002; Lin et al., 2007).

The direction of wind was reversed (from Asia towards Peru) in El Nino period that cause course dust particles blown away from sea surface and increase the fine dust particles produced from biomass burning. Atmospheric dust input was recognised as an important source of trace elements including $\mathrm{Fe}$ and $\mathrm{Al}$ (Baker \& Jickells, 2017; Strzelec et al., 2020). Surface water nutrient may also derive from the 
sediment via water mixing. Based on vertical distribution of $\mathrm{DFe}$ at study area (Idrus et al., 2016), it showed that DFe concentration was higher at deeper water than surface water at Area I indicating that nutrient was significantly affected by input from sediment. Meanwhile, Areas II and III showed the opposite trend in which higher DFe were observed at surface water then decreased towards bottom indicated that these areas were less affected by input from

Table 2. The coordinates, TFe, DFe, TAl and DAl concentrations for each station from 17 August 2015 to 5 October 2015 at Sarawak water (aerosol)

\begin{tabular}{cccccccc}
\hline Area & St. & $\begin{array}{c}\text { Longitude } \\
\left({ }^{\circ} \mathrm{E}\right)\end{array}$ & $\begin{array}{c}\text { Latitude } \\
\left({ }^{\circ} \mathrm{N}\right)\end{array}$ & $\begin{array}{c}\mathrm{TFe} \\
\left(\mathrm{mg} / \mathrm{m}^{3}\right)\end{array}$ & $\begin{array}{c}\mathrm{DFe} \\
\left(\mathrm{mg} / \mathrm{m}^{3}\right)\end{array}$ & $\begin{array}{c}\text { TAl } \\
\left(\mathrm{mg} / \mathrm{m}^{3}\right)\end{array}$ & $\begin{array}{c}\text { DAl } \\
\left(\mathrm{mg} / \mathrm{m}^{3}\right)\end{array}$ \\
\hline I & 1 & 113.022 & 004.020 & $5.15 \pm 0.65$ & $0.73 \pm 0.01$ & $0.41 \pm 0.04$ & $0.05 \pm 0.01$ \\
& 2 & 112.327 & 003.374 & $4.18 \pm 0.34$ & $0.58 \pm 0.01$ & $0.42 \pm 0.09$ & $0.06 \pm 0.01$ \\
& 3 & 111.127 & 003.131 & $4.27 \pm 0.23$ & $0.57 \pm 0.03$ & $0.42 \pm 0.01$ & $0.06 \pm 0.01$ \\
& 4 & 111.122 & 003.371 & $4.79 \pm 0.81$ & $0.68 \pm 0.03$ & $0.38 \pm 0.12$ & $0.05 \pm 0.01$ \\
II & 5 & 111.423 & 004.171 & $5.19 \pm 0.21$ & $0.72 \pm 0.07$ & $0.43 \pm 0.09$ & $0.06 \pm 0.02$ \\
& 6 & 111.203 & 004.396 & $4.81 \pm 0.88$ & $0.68 \pm 0.01$ & $0.45 \pm 0.01$ & $0.07 \pm 0.01$ \\
& 7 & 110.092 & 003.201 & $2.51 \pm 0.09$ & $0.35 \pm 0.01$ & $0.97 \pm 0.07$ & $0.15 \pm 0.01$ \\
& 8 & 109.599 & 004.171 & $3.26 \pm 0.11$ & $0.45 \pm 0.01$ & $1.00 \pm 0.09$ & $0.16 \pm 0.01$ \\
III & 9 & 112.027 & 005.076 & $6.65 \pm 0.99$ & $0.96 \pm 0.06$ & $1.41 \pm 0.02$ & $0.19 \pm 0.01$ \\
& 10 & 112.203 & 005.390 & $6.78 \pm 1.11$ & $0.94 \pm 0.06$ & $0.94 \pm 0.06$ & $0.15 \pm 0.01$ \\
& 11 & 111.029 & 005.027 & $8.99 \pm 0.32$ & $0.92 \pm 0.05$ & $0.87 \pm 0.03$ & $0.11 \pm 0.01$ \\
& 12 & 110.276 & 004.275 & $4.30 \pm 0.13$ & $0.60 \pm 0.01$ & $0.75 \pm 0.09$ & $0.12 \pm 0.01$ \\
& 13 & 110.123 & 004.480 & $4.25 \pm 0.94$ & $0.60 \pm 0.02$ & $1.05 \pm 0.09$ & $0.15 \pm 0.02$ \\
\hline
\end{tabular}

[TFe] Total Fe; [DFe] Dissolved Fe; [TAl] Total Al; [DAl] Dissolved Al

sediment. Aerosol loading into surface water may increase the productivity by increasing the biological production (Mahowald et al., 2018), as shown at the most oligotrophic area in SCS (i.e. the southern-central SCS) in which the upwelling activities were absent but the Chl- $a$ were elevated in July-August, consistent with the increment of the AOT (Lin et al., 2009). However, the amplitude of Chl- $a$ was low. High $\mathrm{Fe}$ and $\mathrm{Al}$ concentrations at Area I may relate to nutrients sources from the surrounding land and from bottom sediment (Idrus et al., 2016), as nutrients from bottom sediments were supplied throughout the water column during water mixing aiding by effect of strong wind of NE monsoon (Adiana et al., 2014). In contrast, high concentrations of $\mathrm{Fe}$ and $\mathrm{Al}$ in Area III can be related to input from long-range transported atmospheric dusts. TFe, DFe, TAl, and DAl concentrations in this study were higher as compared to study by Hsu et al. (2014) at northern SCS, but considerably lower than value from the East Asian region (Hsu et al., 2013). Distance from source of biomass burning possibly affects the distribution of trace metals in the aerosol samples. Guo et al. (2012) stated that impact of atmospheric input to increase the total biomass of phytoplankton was more significant in an oligotrophic open seawater rather than nutrient rich coastal region. These factors may be related to our study as there were absent of upwelling activities along Sarawak EEZ waters.

Solubility of $\mathrm{Fe}$ in aerosol at study location showed that $\mathrm{Fe}(17.78 \%)$ has a higher solubility than $\mathrm{Al}(15.21 \%)$, consistent with the study by Chance et al. (2015) which obtained Fe, Mn and $\mathrm{Al}$ solubility in aerosol $(<20 \%)$. This result may be related to input of anthropogenic materials sources from biomass burning activities. Atmospheric deposition into seawater occurs via two path either dry or/and wet deposition. In this study, atmospheric deposition was focused on dry deposition due to absent of rain water samples. In addition, the samplings were conducted during dry season thus dry deposition can be assumed as the main route of atmospheric deposition into the seawater. The atmospheric dust deposition calculated in this study is $1.62 \times 10^{-4} \mathrm{~g} / \mathrm{m}^{2} / \mathrm{yr}$. The total atmospheric flux of $\mathrm{Fe}$ and $\mathrm{Al}$ are $6.11 \times 10^{-7} \mathrm{~mol} / \mathrm{m}^{2} /$ year $(\mathrm{Fe})$ and $2.03 \times 10^{-6} \mathrm{~mol} / \mathrm{m}^{2} /$ year $(\mathrm{Al})$, while the dissolved atmospheric fluxes obtained in this study are $1.09 \times 10^{-9} \mathrm{~mol} / \mathrm{m}^{2} /$ year $(\mathrm{Fe})$ and $3.09 \times 10^{-7}$ $\mathrm{mol} / \mathrm{m}^{2} /$ year $(\mathrm{Al})$. Residence times obtained in this study are 0.92 years (DFe) and 1.31 years (DAl). 
The relationship between concentration distributions of $\mathrm{DFe}$ and $\mathrm{DAl}$ relative to distance from shoreline showed that the concentration of both trace metals were increased exponentially with increasing distance from shoreline $\left(\mathrm{R}^{2}=\right.$ 0.8027, $\left.[\mathrm{DFe}](\mathrm{nM})=33.899 \mathrm{e}^{0.002 x}\right)$ and $\left(\mathrm{R}^{2}=\right.$ 0.957, [DAl] $\left.(\mathrm{nM})=5.6421 \mathrm{e}^{0.0017 \mathrm{x}}\right)$. The horizontal fluxes were calculated to determine the rate of DFe and DAl fluxes from nearby land towards offshore. In this study, lateral flux of
$\mathrm{DFe}$ is $0.10 \mathrm{nmol} / \mathrm{m}^{2} /$ day or $37.08 \mathrm{nmol} / \mathrm{m}^{2} /$ year, and the lateral flux of DAl calculated is 0.35 $\mathrm{nmol} / \mathrm{m}^{2} /$ day or $125 \mathrm{nmol} / \mathrm{m}^{2} /$ year. Comparison between $\mathrm{DFe}$ and DAl atmospheric fluxes with lateral fluxes showed that atmospheric input was the most prominent sources of DFe and DAl rather than lateral fluxes. Therefore, $\mathrm{Fe}$ and $\mathrm{Al}$ fluxes (i.e. from the atmospheric deposition and the lateral deposition) estimated in this can be summarized as in Figure $3 \mathrm{Fe}$ that is

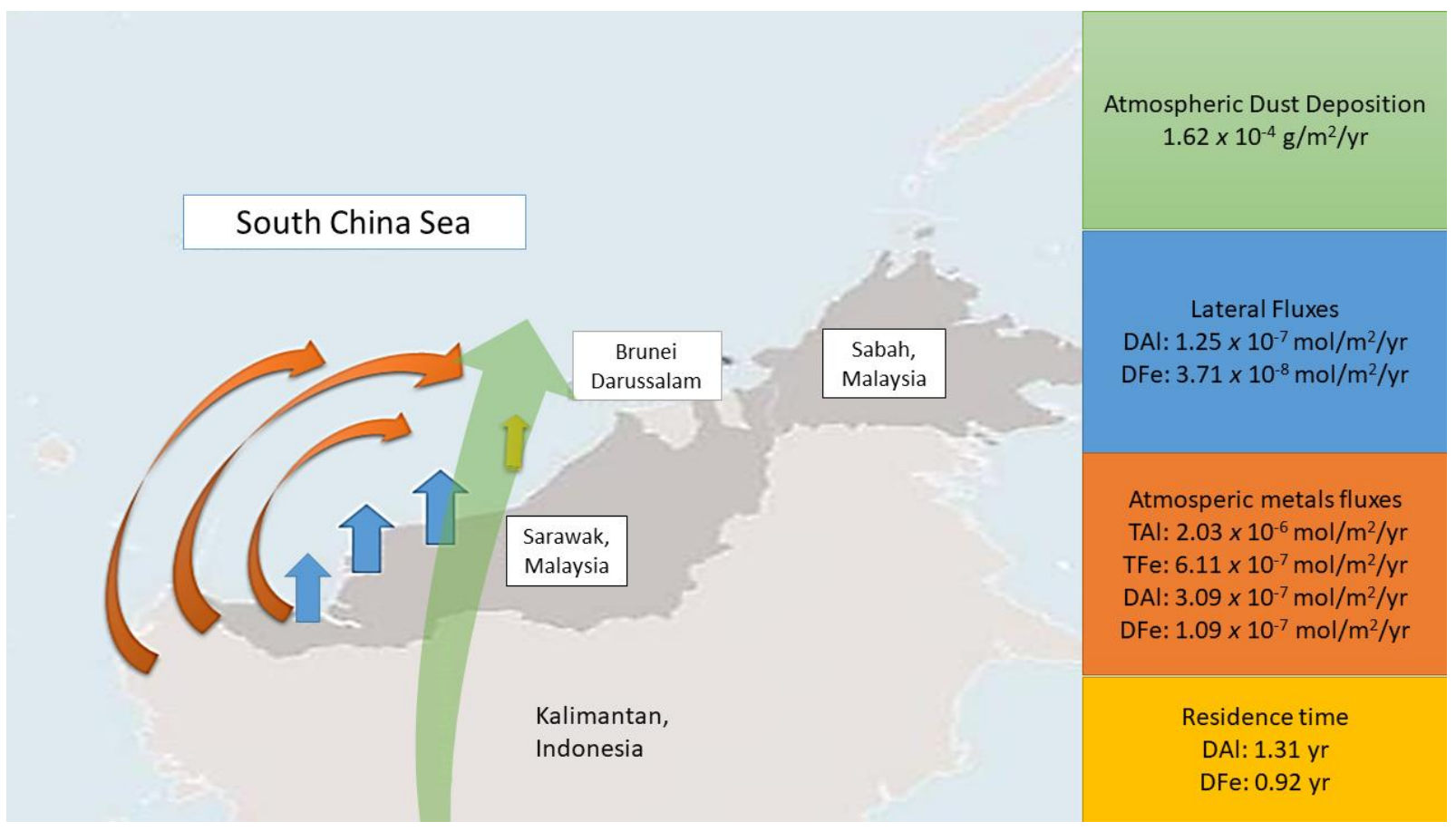

Figure 3. Inputs of $\mathrm{Fe}$ and $\mathrm{Al}$ into the SCS off Sarawak Waters during the haze event. Green arrow indicates the atmospheric dust deposition, orange arrows represent atmospheric metals ( $\mathrm{Fe}$ and $\mathrm{Al}$ ) fluxes, blue arrows show the latera fluxes from the land, and the yellow arrow is for the residence time of metals.

biologically available to be used by marine microorganism is in dissolved form. DFe distribution in surface water at our study area was significantly affected by atmospheric input indicated by the same patterns of DFe with DAl distributions. The distribution of $\mathrm{Fe}$ in seawater is controlled by rate of $\mathrm{Fe}$ stabilisation (formation of organic binding ligands) and $\mathrm{Fe}$ removal processes (Hopwood et al., 2020; Shaked et al., 2020). Marine organism (i.e. phytoplankton) will produce organic ligands to enable DFe uptake for their biological processes (Shaked et al., 2020; Ventura et al., 2021). Thus, DFe concentration in coastal water and open ocean was strongly influenced by existence of natural iron-complexing organic ligands as > 99\% of chemical speciation of dissolved $\mathrm{Fe}$ dominated by organic complexes (Shaked et al., 2020; Mohamed et al., 2011). Table 3 highlights the Fe speciation data obtained from 3 stations 
Table 3. Fe speciation data for selected stations at three different areas

\begin{tabular}{ccccccccc}
\hline Station & Area & Depth $(\mathrm{m})$ & $\begin{array}{c}{[\mathrm{DFe}]} \\
(\mu \mathrm{M})\end{array}$ & $\begin{array}{c}{\left[\mathrm{L}_{\mathrm{T}}\right]} \\
(\mu \mathrm{M})\end{array}$ & $\begin{array}{c}{\left[\mathrm{L}^{\prime}\right]} \\
(\mu \mathrm{M})\end{array}$ & $\begin{array}{c}\text { Log K } \\
\left(\mathrm{mol}^{1}\right)\end{array}$ & {$[\mathrm{LT}] /[\mathrm{DFe}]$} & FeL $(\%)$ \\
\hline 48 & I & 3 & 1.08 & 1.05 & 0.00 & 22.43 & 0.97 & 97.1 \\
108 & II & 3 & 1.07 & 1.13 & 0.06 & 23.32 & 1.05 & 105.0 \\
130 & III & 3 & 3.21 & 3.20 & 0.00 & 24.33 & 1.00 & 99.8 \\
\hline
\end{tabular}

[DFe] dissolved Fe concentration; [ $\left.\mathrm{L}_{\mathrm{T}}\right]$ total binding ligand; [L'] free iron binding-ligand; Log K stability constant of Fe ligand

representing each study area. Ligand concentration and ligand stability constant pattern are: Area III > Area II > Area I. Several studies on iron(III) speciation reported that generally $\left[\mathrm{L}_{\mathrm{T}}\right]$ was higher than $\mathrm{DFe}$ in surface water either in coastal water or open ocean (Cullen et al., 2006; Boye et al., 2001, 2005; Croot et al., 2004), as observed at Area II. Excess organic ligands were produced by phytoplankton in ways to prevent precipitation of DFe enabling it to be biologically uptake. However, excess concentration of DFe was observed at Areas I and III resembled result of study conducted at Sulu Sea and Celebes Sea by Kondo et al. (2007). DFe concentration at Sulu and Celebes Seas were from $0.46 \mathrm{nM}$ to $1.48 \mathrm{nM}$ while $\mathrm{L}_{\mathrm{T}}$ range obtained was from 0.43 to 1.09 $\mathrm{nM}$, respectively. Excess DFe in surface water $\left(\mathrm{DFe}>\mathrm{L}_{\mathrm{T}}\right)$ occurred due to several possibilities including the present of $\mathrm{DFe}$ iron hydroxide particles (colloidal $\mathrm{Fe}$ ). Besides that, organic or/and inorganic complexes of DFe with weak ligands might not be detected during the analysis due to limitation of our method (Mohamed et al., 2011). For Area I, DFe may also supplied from coastal via riverine input supported by reported value of salinity at Station 48 which was lower compared to Stations 108 and 130 (Idrus et al., 2016). Area III was analysed with highest ligand concentration $\left(\mathrm{L}_{\mathrm{T}}: 3.20 \mu \mathrm{M}\right)$ and strongest organic ligands ( $\log k$ : 24.33). Production process of organic ligands could differ between different areas controlled by sources of organic ligands itself. Possible sources of organic ligands in Area III were from atmospheric dust input either via dry or wet deposition. In addition, highest average concentration of Chl- $a$ was analysed at Area III. Organic ligand was also biologically produced by bacteria and phytoplankton (Blanco-Ameijeiras et al., 2020; Ardiningsih et al., 2021) as well as during the plankton cell lysis (Poorvin et al., 2004). Thus, high abundance of Chl- $a$ at Area III could support the production of more strong class of organic ligands than Area I and Area II. The stability constant range measured in our study ( $\log \mathrm{K} ; 22.43-24.33)$ was higher than Kondo et al. (2007), at different area with the same application method. They reported that $\log \mathrm{K}$ obtained at Sulu Sea, Philippine Sea, Celebes Sea, and South China Sea was 22.4 to 22.6, 23.3, 23.0 and 22.0, respectively. Log K obtained at coastal and open ocean water was 19.5-22.3 and 21.4-22.7, respectively (Mohamed et al., 2011; Cullen et al., 2006; Croot et al., 2004; Croot \& Johansson, 2000). However, there were some locations that analysed with strong $\mathrm{Fe}$ organic ligands such as Sulu and adjacent Seas (log K 22.0-24.0), Southern Ocean and equatorial Pacific Ocean ( $\log \mathrm{K}>23$ ) (Kondo et al., 2007; Nolting et al., 1998; Rue \& Bruland, 1995), due to the intensidied light exposure and located at the shelf (Ardiningsih et al., 2021).

\section{CONCLUSION}

This study has provided information on the dust deposition, atmospheric of total and dissolved $\mathrm{Fe}$ and $\mathrm{Al}$ fluxes, dissolved $\mathrm{Fe}$ and $\mathrm{Al}$ fluxes in the surface waters, and $\mathrm{Fe}$ ligands in the southern part of SCS (Sarawak waters, Malaysia Borneo) for the first time after 20 years. Higher atmospheric of total $\mathrm{Fe}$ and $\mathrm{Al}$ fluxes compared to dissolved $\mathrm{Fe}$ and $\mathrm{Al}$ fluxes indicated that dust particles from the haze were the main sources of those trace metals at the study areas. Moreover, the dissolved Fe and $\mathrm{Al}$ fluxes on the surface waters from the nearby lands were considerably low. Al distribution data suggested that atmospheric dust deposition significantly enhance propagation of phytoplankton biomass along with Fe uptake. The uptake of Fe by phytoplankton possibly via production of natural organic $\mathrm{Fe}$ (III) binding ligands. Future studies should focus on understanding the role of natural organic $\mathrm{Fe}$ (III) binding ligands in this area along with phytoplankton analysis. 


\section{ACKNOWLEDGEMENTS}

The authors are gratefully acknowledging the FRI Bintawa, Sarawak for providing an opportunity to conduct this research during demersal fish survey, and UNIMAS for research financial support through the SGS grant F017(S145)/1175/2014(10). Thank you to Faculty of Environment, UPM for giving an opportunity to use the aerosol sampler and voltammetry.

\section{REFERENCES}

Adiana, G., Shazili, N., Marinah, M. \& Bidai, J. (2014). Effects of northeast monsoon on trace metal distribution in the South China Sea off Peninsular Malaysia. Environmental Monitoring and Assessment, 186(1): 421-431. DOI: $\quad$ https://doi.org/10.1007/s10661-0133387-9

Ali, M. \& Shakrani, S. (2014). A comparison of ICPOES and UV-Vis spectrophotometer for heavy metals determination in soil irrigated with secondary treated wastewater. International Journal of Civil and Environmental Engineering, 14: 8-15.

Ardiningsih, I., Seyitmuhammedov, K., Sander, S. G., Stirling, C. H., Reichart, G. J., Arrigo, K. R., Gerringa, L. J. A. \& Middag, R. (2021). Febinding organic ligands in coastal and frontal regions of the western Antarctic Peninsula. Biogeosciences, 18: 4587-4601. DOI: https://doi.org/10.5194/bg-18-4587-2021

Baker, A. R. \& Jickells, T. D. (2017). Atmospheric deposition of soluble trace elements along the Atlantic Meridional Transect (AMT). Progress in Oceanography, 158: 41-51. DOI: http://dx.doi.org/10.1016/j.pocean.2016.10.002

Berman-Frank, I., Bidle, K. D., Haramaty, L., \& Falkowski, P. G. (2004). The demise of the marine cyanobacterium, Trichodesmium spp., via an autocatalyzed cell death pathway. Limnology and oceanography, 49: 997-1005. DOI: https://doi.org/10.4319/lo.2004.49.4.0997

Blanco-Ameijeiras, S., Carbanes, D. J. E., Cable, R. N., Trimborn, S., Jacquest, S., Wiegmann, S., Völkner, C., Lelchat, F., Bracher, A., Duhaime, M. B. \& Hassler, C. S. (2020). Exopolymeric Substances Control Microbial Community Structure and Function by Contributing to Both $\mathrm{C}$ and $\mathrm{Fe}$ Nutrition in Fe-Limited Southern Ocean Provinces. Microorganisms, 8(12):
1980. DOI: https://doi.org/10.3390/ microorganisms 8121980

Boonyapiwat, S. (2000). Species composition, abundance and distribution of phytoplankton in the thermocline layer in the South China Sea, Area IV: Vietnamese Waters. Paper presented at the Proceedings of the SEAFDEC Seminar on Fishery Resources in the South China Sea, Area IV: Vietnamese Waters. DOI: http://hdl.handle.net/20.500.12066/4379

Boye, M., Nishioka, J., Croot, P. L., Laan, P., Timmermans, K. R. \& de Baar, H. J. (2005). Major deviations of iron complexation during 22 days of a mesoscale iron enrichment in the open Southern Ocean. Marine Chemistry, 96(3): 257-271. DOI: https://doi.org/10.1016/ j.marchem.2005.02.002

Boye, M., van den Berg, C. M., de Jong, J. T., Leach, H., Croot, P., \& de Baar, H. J. (2001). Organic complexation of iron in the Southern Ocean. Deep Sea Research Part I: Oceanographic Research Papers, 48(6): 1477-1497. DOI: https://doi.org/ 10.1016/S0967-0637(00) 00099-6

Brown, M. T. \& Bruland, K. W. (2008). An improved flow-injection analysis method for the determination of dissolved aluminum in seawater. Limnology Oceanography Methods, 6: 87-95. DOI: https://doi.org/10.4319/lom. 2008.6.87

Cattau, M., Marlier, M. E. \& DeFries, R. (2016). Effectiveness of roundtable on sustainable palm oil (RSPO) for reducing fires on oil palm concessions in Indonesia from 2012 to 2015. Environmental Research Letters, 11: 105007. DOI: https://doi.org/ 10.1088/1748-9326/11/ $10 / 105007$

Chance, R., Jickells, T. D. \& Baker, A. R. (2015). Atmospheric trace metal concentrations, solubility and deposition flux in remote marine air over the south-east Atlantic. Marine Chemistry, 177: 45-56. DOI: http://dx.doi.org/10.1016/ j.marchem.2015.06.028

Chen, C., Huang, L., Shi, J., Zhou, Y., Wong, J., Yao, X., Gao, H., Liu, Y., Xing, J. \& Liu, X. (2021). Atmospheric outflow of anthropogenic iron and its deposition to China adjacent seas. Science of the Total Environment, 750: 141302. DOI: https://doi.org/10.1016/j.scitotenv.2020.14130 2

Crippa, P., Castruccio, S., Archer-Nicholls, S., Lebron, G. B., Kuwata, M., Thota, A., Sumin, S., Butt, E., Wiedinmyer, C. \& Spracklen, D. V. (2016). Population exposure to hazardous air 
quality due to the 2015 fires in Equatorial Asia. Scientific Reports, 6: 37074. DOI: https://doi.org/10.1038/srep37074

Croot, P. L., Andersson, K., Öztürk, M. \& Turner, D. R. (2004). The distribution and speciation of iron along $6 \mathrm{E}$ in the Southern Ocean. Deep Sea Research Part II: Topical Studies in Oceanography, 51(22): 2857-2879. DOI: https://doi.org/10.1016/ j.dsr2.2003.10.012

Cullen, J. T., Bergquist, B. A. \& Moffett, J. W. (2006). Thermodynamic characterization of the partitioning of iron between soluble and colloidal species in the Atlantic Ocean. Marine Chemistry, 98(2): 295-303. DOI: https://doi.org/10.1016/ j.marchem. 2005. 10.007

de Jong, J. T., Boyé, M., Gelado-Caballero, M. D., Timmermans, K. R., Veldhuis, M. J., Nolting, R. F., van den Berg, C. M. \& de Baar, H. J. (2007). Inputs of iron, manganese and aluminium to surface waters of the Northeast Atlantic Ocean and the European continental shelf. Marine Chemistry, 107(2): 120-142. DOI: https://doi.org/10.1016/j.marchem.2007.05.007

Du, S., Ariful Islam, G. M., Xiang, R. \& Yang, X. (2021). The dust deposition process and biogeohemical impacts in the Northern South China Sea. Asia-Pacific Journal of Atmospheric Sciences, 57: 77-87. DOI: https://doi.org/10.1007/s13143-019-00171-4.

Gehlen, M., Heinze, C., Maier-Reimer, E. \& Measures, C. (2003). Coupled Al-Si geochemistry in an ocean general circulation model: A tool for the validation of oceanic dust deposition fields? Global Biogeochemical Cycles, 17(1): 1028. DOI: https://doi.org/10. 1029/2001GB001549

Global Volcanism Program, 2013. Volcanoes of the World, v. 4.7.6. Venzke, E (ed.). Smithsonian Institution. Downloaded 27 Feb 2019. Retrieved from: https://doi.org/10.5479/si.G VP.VOTW4-2013

Guo, C., Yu, J., Ho, T. Y., Wang, L., Song, S., Kong, L. \& Liu, H. (2012). Dynamics of phytoplankton community structure in the South China Sea in response to the East Asian aerosol input. Biogeosciences, 9(4): 1519-1536. DOI: https://doi.org/ 10.5194/bg-9-1519-2012

Hapsari, K.A., Biagioni, S., Jennerjahn, T.C., Saad, A., Sabiham, S., Corre, M.D., Veldkamp, E. \& Behling, H. (2021). Late Holocene ENSOrelated fire impact on vegetation, nutrient status and carbon accumulation of peatlands in Jambi, Sumatra, Indonesia. Review of Paleobotany and Palynology, 293: 104482. DOI: https://doi.org/10.1016/j.revpalbo.2021.104482

Ho, T. Y., Chou, W. C., Wei, C. L., Lin, F. J., Wong, G. T. \& Lin, H. L. (2010). Trace metal cycling in the surface water of the South China Sea: vertical fluxes, composition, and sources. Limnology and Oceanography, 55(5), 18071820. DOI: https://doi.org/10.4319/lo.2010 .55 .5 .1807

Holloway, T., Levy, I. H. \& Carmichael, G. (2002). Transfer of reactive nitrogen in Asia: development and evaluation of a sourcereceptor model. Atmospheric Environment, 36(26): 4251-4264. DOI: https://doi.org/ $10.1016 / \mathrm{S} 1352-2310(02) 00316-3$

Hopwood, M.J., Santana-González, C., GallegoUrrea, J., Sanchez, N., Achterberg, E.P., Ardelan, M.V., Gledhill, M., González-Dávila, M., Hoffmann, L., Leiknes, Ø., SantanaCasiano, J.M., Tsagaraki, T.M. \& Turner, D. (2020). Fe(II) stability in coastal seawater during experiments in Patagonia, Svalbard, and Gran Canaria. Biogeosciences, 17: 1327-1342. DOI: https://doi.org/10.5194/bg-17-1327-2020

Hsu, S. C., Gong, G. C., Shiah, F. K., Hung, C. C., Kao, S. J., Zhang, R. \& Lin, F. J. (2014). Sources, solubility, and acid processing of aerosol iron and phosphorous over the South China Sea: East Asian dust and pollution outflows vs. Southeast Asian biomass burning. Atmospheric Chemistry and Physics Discussions, 14(15): 21433-21472. DOI: https://doi.org/10.5194/acpd-14-21433-2014

Hsu, S. C., Tsai, F., Lin, F. J., Chen, W. N., Shiah, F. K., Huang J, C., Chan, C. Y., Chen, C. C., Liu, T. H. \& Chen, H. Y. (2013). A super Asian dust storm over the East and South China Seas: Disproportionate dust deposition. Journal of Geophysical Research: Atmospheres, 118(13): 7169-7181. DOI: https://doi.org/ 10.1002/jgrd. 50405

Huang, S. J. \& Lin, C. C. (2015). Distribution of Atmospheric Aerosol over the South China Sea. Advances in Meteorology, 2015(1): 1-7. DOI: https://doi.org/ 10.1155/2015/692762

Idrus, F. A., Rahim, N. S. A., Mohamed, K. N., Chong, M. D., Basri, M. M. \& Musel, J. (2016). Studies on vertical profiles of physicochemical characteristics at Sarawak EEZ waters. In M. Samsur, M. L. Shabdin, L. Nyanti, A. R. Khairul Adha, R. Hadil \& J. M. Mobilik (Eds.), 
Aquatic Science Colloqium 2016: Experience Sharing in Aquatic Science Research IV: Malaysia Exclusive Economic Zone (EEZ) Cruise and other Aquatic Science Research (pp. 113-127). Monograph, Department of Aquatic Science, Universiti Malaysia Sarawak, Kota Samarahan, Sarawak, Malaysia. DOI: http://ir.unimas.my/id/eprint/19660

Idrus, F.A. (2016) Distributions of Dissolved Manganese in the Surface Waters of the Tropical North-Eastern Atlantic Ocean. Borneo Journal of Resource Science and Technology, 6(2): 1-10. DOI: https://doi.org/10.3373 6/bjrst.337.2016

Idrus, F.A., Chong, M.D., Rahim, N.S.A., Basri, M. M. \& Musel, J. (2017). Physicochemical parameters of surface seawater in Malaysia Exclusive Economic Zones off the coast of Sarawak. Borneo Journal of Resource Science and Technology, 7(1): 1-10. DOI: https://doi.org/10.33736/bjrst.388.2017

Jickells, T., An, Z. S., Andersen, K. K., Baker, A. R, Bergametti, G., Brooks, N., Cao, J. J., Boyd, P. W., Duce, R. A. \& Hunter, K. A. (2005). Global iron connections between desert dust, ocean biogeochemistry, and climate. Science, 308(5718): 67-71. DOI: https://doi.org/ 10.1126/science. 1105959

Kondo, Y., Takeda, S. \& Furuya, K. (2007). Distribution and speciation of dissolved iron in the Sulu Sea and its adjacent waters. Deep Sea Research Part II: Topical Studies in Oceanography, 54(1): 60-80. DOI: https://doi.org/10.1016/j.dsr2.2006. 08.019

Koplitz, S. N., Mickley, L. J., Marlier, M. E., Buonocore, J. J., Kim, P. S., Liu, T., Sulprizio, M. P., DeFries, R. S., Jacob, D. J., Schwartz, J., Pongsiri, M. \& Myers, S. S. (2016). Public health impacts of the severe haze in Equatorial Asia in September-October 2015: demonstration of a new framework for informing fire management strategies to reduce downwind smoke exposure. Environmental Research Letters, 11: 094023. DOI: https://doi.org/10.1088/17489326/11/9/094023

Kraemer, S. M. (2004). Iron oxide dissolution and solubility in the presence of siderophores. Aquatic Sciences, 66(1): 3-18. DOI: https://doi.org/10.1007/s00027- 003-0690-5

Li, F., Ren, J., Yan, L., Liu, S., Liu, C., Zhou, F. \& Zhang, J. (2013). The biogeochemical behavior of dissolved aluminium in the southern Yellow Sea: Influence of the spring phytoplankton bloom. Chinese Science Bulletin, 58(2): 238248. DOI: https://doi.org/10.1007/ s11434-012$5512-5$

Lin, I. I., Chen, J. P., Wong, G. T., Huang, C. W. \& Lien, C. C. (2007). Aerosol input to the South China Sea: Results from the MODerate Resolution Imaging Spectro-radiometer, the quick scatterometer, and the measurements of pollution in the troposphere sensor. Deep Sea Research Part II: Topical Studies in Oceanography, 54(14): 1589-1601. DOI: https://doi.org/ 10.1016/j.dsr2.2007.05.013

Lin, I. I., Wong, G. T., Lien, C. C., Chien, C. Y., Huang, C. W. \& Chen, J. P. (2009). Aerosol impact on the South China Sea biogeochemistry: An early assessment from remote sensing. Geophysical Research Letters, 36(17), L17605. DOI: https://doi.org/10.1029/ 2009GL037484

Mahowald, N.M., Hamilton, D. S., Mackey, K. R. M., Moore, J. K., Baker, A. R., Scanza, R. A. \& Zhang, Y. (2018). Aerosol trace metal leaching and impacts on marine microorganisms. Nature Communication, 9: 2614. DOI: https://doi.org/ 10.1038/s41467-018-04970-7

Mohamed, K. N, Godon, E., Johan, S. \& Jaafar, F. S. (2019). Distribution of dissolved Aluminium (dAl) in seawarer at Pulau Perhentian, Terengganu. Malaysian Journal of Analytical Sciences, 23(6): 1044-1053. DOI: https://doi.org/10.17576/ mjas-2019-2306-12.

Mohamed, K. N., Steigenberger, S., Nielsdottir, M. C., Gledhill, M. \& Achterberg, E. P. (2011). Dissolved iron (III) speciation in the high latitude North Atlantic Ocean. Deep Sea Research Part I: Oceanographic Research Papers, 58(11): 1049-1059. DOI: https://doi.org/10.1016/ j.dsr.2011. 08.011

Nolting, R., Gerringa, L., Swagerman, M., Timmermans, K. \& de Baar, H. (1998). Fe (III) speciation in the high nutrient, low chlorophyll

Pacific region of the Southern Ocean. Marine Chemistry, 62(3), 335-352. DOI: https://doi.org/10.1016/S0304-4203(98)000462

Ponette-Gonzalez, A. G., Curran, L. M., Pittman, A. M., Carlson, K. M., Steele, B. G., Ratnasari, D., Mujiman \& Weathers, K. C. (2016). Biomass burning drives atmospheric nutrient redistribution within forested peatlands in Borneo. Environmental Research Letters, 11: 
085003. DOI: https://doi.org/10.1088/ 17489326/11/8/085003

Poorvin, L., Rinta-Kanto, J. M., Hutchins, D. A. \& Wilhelm, S. W. (2004). Viral release of iron and its bioavailability to marine plankton. Limnology and Oceanography, 49(5): 1734$1741 . \quad$ DOI: 10.4319/lo.2004.49.5.1734

https://doi.org/

Rijkenberg, M. J., Powell, C. F., DAll'Osto, M., Nielsdottir, M. C., Patey, M. D., Hill, P. G., Baker, A. R., Jickells, T. D., Harrison, R. M. \& Achterberg, E. P. (2008). Changes in iron speciation following a Saharan dust event in the tropical North Atlantic Ocean. Marine Chemistry, 110(1), 56-67. DOI: https://doi.org/10.1016/j.marchem.2008.02.006

Rue, E. L., \& Bruland, K. W. (1995). Complexation of iron (III) by natural organic ligands in the Central North Pacific as determined by a new competitive ligand equilibration/ adsorptive cathodic stripping voltammetric method. Marine Chemistry, 50(1): 117-138. DOI: https://doi.org/ 10.1016/ 0304-4203(95)00031$\mathrm{L}$

Sarthou, G., Baker, A. R., Blain, S., Achterberg, E. P., Boye, M., Bowie, A. R., Croot, P., Laan, P., de Baar, H. J. W. \& Jickells, T. D. (2003). Atmospheric iron deposition and sea-surface dissolved iron concentrations in the eastern Atlantic Ocean. Deep Sea Research Part I: Oceanographic Research Papers, 50(10): 1339-1352. DOI: https://doi.org/10.1016/ S0967-0637(03)00126-2

Shaked, Y., Buck, K. N., Mellett, T. \& Maldonado, M.T. (2020). Insights into the bioavailability of oceanic dissolved Fe from phytoplankton uptake kinetics. The ISME Journal, 14: 1182-1193. DOI: https://doi.org/10.1038/s41396-020-0597-3

Shi, J., Guan, Y., Ito, A., Gao, H., Yao, X., Baker, A.R. \& Zhang, D. (2020). High production of soluble iron promoted by aerosol acidification in fog. Geophysical Research Letters, 47(12): e2019GL086124. DOI: https://doi.org/ 10.1029/2019GL086124

Strzelec, M., Proemse, B. C., Barmuta, L. A., GaultRingold, M., Desservettaz, M., Boyd, P. W.,
Perron, M. M. G., Schofield, R. \& Bowie, A. R. (2020). Atmospheric Trace Metal Deposition from Natural and Anthropogenic Sources in Western Australia. Atmosphere, 11(5): 474. DOI: https://doi.org/10.3390/atmos11050474

Utoomprurkporn, W. \& Snidvongs, A. (1999). Trace metal concentrations and distributions in sea water of the South China Sea. Area 2: Off Sabah, Sarawak and Brunei Darussalam. Paper presented at the Proceedings of the second Technical Seminar on Marine Fishery Resources Survey in the South China Sea, Area 2: Sarawak, Sabah and Brunei Darussalam waters. 14-15 December 1998, Kuala Lumpur, Malaysia. DOI: http://hdl.handle.net/20.500. $12067 / 815$

Ventura, A., Simoes, E. F. C., Almeida, A. S., Martins, R., Duarte, A. C., Louveiro, S. \& Duarte, R. M. B. O. (2021) Deposition of aerosols onto upper ocean and their impacts on marine biota. Atmosphere, 12: 684. DOI: https://doi.org/10.3390/ atmos12060684.

Wen, L. S., Jiann, K. T., \& Santschi, P. H. (2006). Physicochemical speciation of bioactive trace metals $(\mathrm{Cd}, \mathrm{Cu}, \mathrm{Fe}, \mathrm{Ni})$ in the oligotrophic South China Sea. Marine Chemistry, 101(1): 104-129.

DOI: https://doi.org/10.1016/j.marchem.2006.01.005

Wong, G. T., Chung, S. W., Shiah, F. K., Chen, C. C., Wen, L. S. \& Liu, K. K. (2002). Nitrate anomaly in the upper nutricline in the northern South China Sea-Evidence for nitrogen fixation. Geophysical Research Letters, 29(23): 2097. DOI: https://doi.org/10.1029/2002GL015796

Wong, G. T., Ku, T. L., Mulholland, M., Tseng, C. M., \& Wang, D. P. (2007). The SouthEast Asian time-series study (SEATS) and the biogeochemistry of the South China Sea- an overview. Deep Sea Research Part II: Topical Studies in Oceanography, 54(14): 1434-1447. DOI: https://doi.org/10.1016/j.dsr2.2007.05. 012

Zhang, X., Zhuang, G., Guo, J., Yin, K. \& Zhang, P. (2007). Characterization of aerosol over the Northern South China Sea during two cruises in 2003. Atmospheric Environment, 41(36): 78217836. DOI: https://doi.org/10.1016/j.atmosenv .2007.06.031 